\title{
Understanding the Importance of Sustainable Buildings in Occupants Environmental Health and Comfort
}

\author{
Okhovat Hanie (Corresponding author) \\ Department of Architecture, Faculty of Art, University of Tarbiat Modares \\ Jalal Ale Ahmad St, Tehran, Iran \\ Tel/Fax: 98-21-7786-4133Ｅ-mail: okhovat@modares.ac.ir \\ Amirkhani Aryan \\ Department of Architecture, Faculty of Art, University of Tarbiat Modares \\ Jalal Ale Ahmad St, Tehran, Iran \\ E-mail: Aryan_Amirkhani@modares.ac.ir \\ Leylian MohammadReza \\ Department of Architecture, Faculty of Art \\ University of Tarbiat Modares, Jalal Ale Ahmad St, Tehran, Iran \\ E-mail: Leylian@modares.ac.ir \\ Leylian Elham \\ Department of Architecture, Lecturer at Azad University of Tehran, West branch
}

\begin{abstract}
Where and how buildings are built affects the ecosystems around us in countless ways. And the buildings themselves create new indoor environments that present new environmental problems and challenges. In addition, the growing use of synthetic materials, solvents and mechanical systems of environmental control within buildings carry threats to health and personal well-being. This paper investigates how indoor environmental quality influences the health and comfort of occupants. The solutions to sustainable indoor environment are reviewed afterwards.

The results show that maintaining the conditions of a building improves the health of its occupants. Meanwhile, with regards to the importance of improving environmental conditions in green buildings, the well-being, health and safety of building occupants and all those potentially affected by a building should be a primary goal of a sustainable architecture.
\end{abstract}

Keywords: Indoor Environment, Quality, Sustainable buildings, Occupants

\section{Introduction}

Evidence indicates that various building aspects influence the health and the comfort of occupants. For example, design characteristics of hospitals, such as better ventilation, layout and lighting, have resulted in reduced stress and fatigue in patients and staff, as well as improvement in overall health [Ulrich et al, 2004]. Similarly, building placement relative to residential and commercial areas influences whether occupants must depend on automobiles or are able to walk, bicycle and use public transit to other destinations [Saelens et al, 2003], [Frank et al, 2005], [Handy et al, 2002]. The conditions of a building affect the health of its users. Lack of safe drinking water, inadequate heating or cooling, waste disposal, and ventilation systems result in adverse health effects, including respiratory illness, asthma, infectious disease, injuries, and mental health disorders. These conditions, which are characteristic of substandard housing, predominantly affect vulnerable populations specifically people of radical minorities [Krieger, Higgins, 2002]. Moreover, susceptibility of poor and minority populations to hazard may be increased due to underlying health conditions [Frumkin, 2002], such as asthma [National Heart, 1995] and cardiovascular disease [Geronimus et al, 1996]. Therefore, maintaining the conditions of a building improves the health of its occupants. The well- being, health, and safety of a building occupants and all those potentially affected by a building is a primary goal of a sustainable architecture. Health goals, on the other hand, relate to all issues dealing with the long term health of the occupants and passers-by. This subsystem also includes factors that are concerned with the satisfaction users have with the building, its space and conditions. This involves notions of comfort or minimizing discomfort as well as protecting physical property within and around a building. This paper investigates how indoor environment greatly affects the occupant's well being. The solutions to sustainable indoor environment are reviewed afterward.

\section{Attending to environmental psychology in buildings}

About a decade ago the term" Sick Building Syndrome" (SBS) was coined to describe the condition where people easily get mental and physical diseases by occupying a particular building [Edwards, 1999]. Psychologist indicated that these buildings had always been criticized for separating their occupants from the natural elements. Kaplan's [Kaplan ,1995] attention restoration theory (ART) posits that natural settings provide an easy fascination that can 
help people recover from the mental fatigue caused by the more effortful attention often required by work. Wilson [Wilson, 1984] addresses that humans have an innate need for contact with the natural world and in particular seek to occupy and recreate in settings that are similar to those from our evolutionary past. Ulrich [Ulrich, 1993] reviews studies supporting hypotheses that humans have innate negative and positive associations with various elements of the natural world.

Kuo and Sullivan [Kuo, Sullivan,2001] have extended these findings by showing that the presence of vegetation in public housing sites is significantly associated with reduced levels of aggressiveness and crime. The hypothesis about the restorative function of natural environment has been tested in many empirical studies. Ulrich [Ulrich et al, 2004] for example founded that hospital patients who could look out on trees and nature from their windows recovered more quickly than whose views restricted to buildings. Schroeder [Schroeder, 1991] has shown that natural environments with vegetation and water induce relaxed and less stressful states in observers compared with urban scenes with no vegetation. This ability of natural elements to function as "natural tranquillizers" may be particularly beneficial in urban areas where stress is an all too common aspect of daily living [Berg et al, 1998]. Later studies have lead to similar results, strengthening the assumption that natural environment have positive influence on psychological and mental health. Not only green areas have significant effect on human behavior, but also natural features seem to affect emotional well being. For example an evaluation of day lighting in schools showed that students in day lit classrooms were happier than those with minimal day lighting in other classrooms [Heschong et al, 2002]. These studies show natural element play an important role in buildings and can simply affect the occupant's psychological behaviors and their well being.

\section{The importance of Environmental health in buildings}

The growing use of synthetic materials, solvents and mechanical systems of environmental control within buildings carry threats to health and personal well-being. The term SBS is used to describe situations in which building occupants experience acute health and comfort effects that appear to be linked to time spent in a building, but no specific illness or cause can be identified [Boxer, 1990]. The complaints may be localized in a particular room or zone, or may be widespread throughout the building. SBS is generally seen as a problem caused by a combination of factors such as poor thermal, visual and aural comfort condition, the presence of gaseous pollutants, microbiological contamination, dust and fibers, and tobacco smoke. SBS is exacerbated when occupants of buildings lack the ability to perceive natural conditions and are unable to control their own internal environmental conditions. On the other hand, the term "building related illness" (BRI) is used when symptoms of diagnosable illness are identified and can be attributed directly to airborne building contaminants. SBS and BRI are associated with acute or immediate health problems.

(See Table 1 and Table 2)

In 1983, World Health Organization Committee reported that up to 30 percent of new and remodeled buildings worldwide may be the subject of excessive complains related to indoor air quality (IAQ) [World Health Organization, 1983]. This condition may have long-term problems in some buildings. Frequently, problems result when a building is operated or maintained in a manner that is inconsistent with its original design or prescribed operating procedures, then indoor air problems are a result of poor building design or occupant activities. It is important to note that complaints may result from other causes. These may include an illness contracted outside the building, acute sensitivity, job related stress or dissatisfaction, and other psychological factors. Nevertheless, studies show that symptoms may be caused or exacerbated by indoor air quality problems [Galea et al, 2005]. Effective control of SBS requires an appreciation of the toxicology of materials, finishes and decorative veneers employed in building, furnishings and furniture. In addition, the quality of the internal environment may be affected by external pollutants finding their way inside such as traffic fumes, radon and landfill gases. As much indoor air quality control is dependent upon using outside air for dilution and displacement of pollutants, the interior environmental quality relies upon clean exterior air. In some town centers, the outside air may be more contaminated than that on the inside. Often SBS problems are dependent upon a combination of factors and the mixing of pollutants and low-level toxicity from many sources. As psychological factors play their part, it has been observed that sealed air-conditioned buildings are more prone to complaints of SBS than buildings ventilated and lit by natural means [Hedge et al, 1996]. Since people spend the majority of their lives indoor the quality of the internal environment greatly affects their mental and physical health. The emergence of deep planned, relatively small windowed office buildings and shops in the 1970s onwards coincided with a growth in health problems. As energy conservation has become more important, buildings have tended to become more highly sealed to control unwanted air filtration. With reduced ventilation rates, the low level toxicity inside become more critical to the well being of building occupants. The period 1970-98 has seen a big increase in synthetic carpeting, the use of adhesives, plywood and particle boards which are known to give off gaseous pollutants. At the same time, the growth in service industries led to greater use of office machines of various kinds which became another source of background pollution through dust and electromagnetic radiation [Benefits of Good IAQ, 2008]. These changes to the office environment have been paralleled in the home where wall-to-wall carpeting (usually incorporating man-made fibers), sealed window systems and the replacement of open fires by central heating, has led to concern over SBS in the domestic sector. This background provides the clues to how a healthier internal environment may 
be created. However for the designers, the rate at which pollution is given off by certain materials is not readily available. The lack of necessary judgmental data means that well-intentioned architects remain in the dark. The concentration of air-borne pollutants from inside buildings may be a hundred times that in the outside air but little is known of their precise origin, whether in paints, cleaning solvent, particle board, pesticide applications, halogens and so on. Hence the task of designing SBS free buildings is particularly difficult [Hedge et al, 1992]. Some pollutants are certainly the result of design decisions, others stem from the nature of maintenance or management contracts, and others are introduced by the occupants themselves.

\section{Main contributing factors in creating SBS}

Studies indicated that 16-37 million cases of colds and flu could be avoided by improving indoor environmental quality, resulting in \$6-\$14 billion annual savings in the United States [Fisk et al, 2002]. The symptoms of SBS might also be reduced $20-50 \%$, resulting in $\$ 10-\$ 30$ billion annual savings in the United States[Milton et al,2000], Similarly, people seem to experience more headaches, dizziness, and tiredness when toxic materials are present [Wargocki et al,1999] Therefore it is significant to address the main causes of sick building syndrome. The following points have been cited main causes of or contributing factors to SBS:

\subsection{Inadequate ventilation:}

In the mid 1900's, building ventilation standards called for approximately 15 cubic feet per minute (cfm) of outside air for each building occupant, primarily to dilute and remove body odors. As a result of the 1973 oil embargo, however, national energy conservation measures called for a reduction in the amount of outdoor air provided for ventilation to $5 \mathrm{cfm}$ per occupant. In many cases, these reduced outdoor air ventilation rates were found to be inadequate to maintain the health and comfort of building occupants. In the USA, investigations carried out up to the end of 1983 by the National Institute for Occupational Safety and Health (NIOSH), a governmental organization, showed 'inadequate ventilation' to be the causal factor in about half of buildings with health complaints (see Table 3) [Sick Building Syndrome ,1990]. Inadequate ventilation, which may also occur if heating, ventilating, and air conditioning (HVAC) systems do not effectively distribute air to people in the building, is thought to be an important factor in SBS. In an effort to achieve acceptable IAQ while minimizing energy consumption, the American Society of Heating, Refrigerating and Air-Conditioning Engineers (ASHRAE) recently revised its ventilation standard to provide a minimum of $15 \mathrm{cfm}$ of outdoor air per person and $20 \mathrm{cfm}$ per person in office spaces. Up to $60 \mathrm{cfm} /$ person may be required in special spaces such as smoking lounges. The amount of adequate ventilation depends on the activities that normally occur in that space [Interpretations to ASHRAE Standard, 1989].

\subsection{Chemical contaminants from indoor sources:}

Most indoor air pollution comes from sources inside the building. For example, adhesives, carpeting, upholstery, manufactured wood products, copy machines, pesticides, and cleaning agents may emit volatile organic compounds (VOCs), including formaldehyde. Environmental tobacco smoke contributes high levels of VOCs. Tobacco smoke is a major source of particulate and gaseous contamination and passive smoking poses direct health risks through contracting lung center and secondary risks by increasing susceptibility to respiratory conditions caused by other sources of indoor pollution. Research shows that some VOCs can cause chronic and acute health effects at high concentrations, and some are known carcinogens. Low to moderate levels of multiple VOCs may also produce acute reactions [Interpretations to ASHRAE Standard, 1989]. Combustion products such as carbon monoxide and nitrogen dioxide can come from unventilated kerosene and gas space heaters, woodstoves, fireplaces and gas stoves.

\subsection{Chemical contaminants from outdoor sources:}

The outdoor air that enters a building can be a source of indoor air pollution. For example, pollutants from motor vehicle exhausts; plumbing vents, and building exhausts such as bathrooms and kitchens, can enter the building through poorly located air intake vents, windows, and other openings. In addition, combustion products can enter a building from a nearby garage.

\subsection{Biological contaminants:}

Bacteria, molds, pollen, and viruses are types of biological contaminants. These contaminants may breed in stagnant water that has accumulated in ducts, humidifiers and drain pans, or where water has collected on ceiling tiles, carpeting, or insulation. Sometimes insects or bird droppings can be a source of biological contaminants. These microbial pollution, which caused by the presence of dust mites leads to asthma attacks in some people and allergic reaction in others. Dampness tends to lead to an increase in the population of dust mites and in the growth of moulds, which through the release of spores, can lead to hay fever attacks. It is though that 10-15 percent of the population is subject to such attacks. If other contaminates are present, such as gaseous pollution given off by particle board, such attacks are more severe and can lead to complicated secondary illness [Clean Med. Conferences, 2003].

Generally, these elements may act in combination, and may supplement other complaints such as inadequate temperature, humidity and lighting. 


\section{Solutions to improve indoor environmental quality}

As SBS and BRI create major physical and mental problems on occupants, it is significant to improve indoor air in buildings. To solve these problems, following suggestions may be appropriate:

\subsection{Increasing ventilation rates:}

It can be a cost effective means of reducing indoor pollutant levels. HVAC systems should be designed, at a minimum, to meet ventilation standards in local building codes; however, many systems are not operated or maintained to ensure that these design ventilation rates are provided. In many buildings, IAQ can be improved by operating the HVAC system to at least its design standard [Interpretations to ASHRAE Standard, 1989]. When there are strong pollutant sources, local exhaust ventilation may be appropriate to exhaust contaminated air directly from the building. Local exhaust ventilation is particularly recommended to remove pollutants that accumulate in specific areas such as rest rooms, copy rooms, and printing facilities.

\subsection{Pollutant source removal or modification:}

It is an effective approach to resolving an IAQ problem when sources are known and control is feasible. Examples include routine maintenance of HVAC systems, such as periodic cleaning or replacement of filters; replacement of water-stained ceiling tile and carpeting; institution of smoking restrictions; venting contaminant source emissions to the outdoors; storage and use of paints, adhesives, solvents, and pesticides in well ventilated areas, and use of these pollutant sources during periods of non-occupancy; and allowing time for building materials in new or remodeled areas to off-gas pollutants before occupancy.

\subsection{Air cleaning:}

It can be a useful adjunct to source control and ventilation but has certain limitations. Particle control devices such as the typical furnace filter are inexpensive but do not effectively capture small particles; high performance air filters capture the smaller, respirable particles but are relatively expensive to install and operate. Mechanical filters do not remove gaseous pollutants. Some specific gaseous pollutants may be removed by adsorbent beds, but these devices can be expensive and require frequent replacement of the adsorbent material. In sum, air cleaners can be useful, but have limited application.

\subsection{Flexible design:}

Designed to give occupants control over their interior environment. For reducing sick building syndrome in buildings and workstations, the building design could easily be modified in an adaptable condition, In other words, the building design should encourage tenant's motivation to control his or her own environment and provide a comfortable condition.

\subsection{Education and communication:}

They are important elements in both remedial and preventive indoor air quality management programs. When building occupants, management, and maintenance personnel fully communicate and understand the causes and consequences of IAQ problems, they can work more effectively together to prevent problems from occurring, or to solve them if they do [World Health Organization, 1983].

\subsection{The location of building:}

Designers should pay attention to the appropriate site location. Buildings should be located where external air quality is high.

\section{Conclusion}

As discussed in this paper, separation from natural elements, often occurs in large buildings, has negative physical and psychological effects on human life. Since there is an increasing attention paid to larger building projects, architects should pay more attention to occupant's health on buildings. This article contributes to a growing dialogue addressing the impacts of sick buildings syndromes and poor indoor environmental quality on human health, by highlighting sustainable strategies that effects the indoor environment and concurrently improve occupants' health. (See Table 4). Adaptation strategies, merit attention because they can help designers to improve the indoor air quality and reduce the illnesses related to buildings.

\section{References}

Benefits of Good IAQ. (2008). http:/www.epa.gov/iaq/schools/benefits.html, last updated on Wednesday, April 9th, 2008.

Berg, A., van den Top, I.M., Kranendonk, R.B. (1998). Natuur wensen van stadsmensen (The Demands on Nature of Urban Citizens) (in Dutch). IBN-DLO Rapport, Wageningen, the Netherlands.

Boxer, P.A. (1990). Indoor air quality: a psychosocial perspective, Journal of Occupational Medicine, 32 , 425-428.

Clean Med. (2003). Conferences for greening health care, www.cleanmed.org

Edwards Brain. (1999). Sustainable Architecture (European directives and building design), Second edition, Architectural Press, London, England. 
Fisk W, Price P, Faulkner D, Sullivan D, Dibartolomeo D. (2002). Worker performance and ventilation: analyses of time series data for a group of call-center workers Paper presented at the indoor air.

Frank LD, Schmid T, Sallis JF, Chapman J, Saelens B. (2005). Linking objective physical activity data with objective measures of urban form: findings from SMARTRAQ. Am J Prev Med; 28(2S):117-25.

Frumkin H. (2002). Urban sprawl and public health. Public Health Rep; 117:201-17.

Galea S, Vlahov D. (2005). Urbanization. In: Frumkin H, ed. Environmental Health: From Global to Local. San Francisco CA: Jossey-Bass.

Geronimus AT, Bound J, Waidmann TA, Hellemeier MM, Burns PB. (1996). Excess mortality among blacks and whites in the United States. N Engl J Med; 335:1552-8.

Handy SL, Boarnet MG, Ewing R, Killingsworth RE. (2002). how the built environment affects physical activity: views from urban planning. Am J Prev Med; 23(2S):64-73.

Hedge, A., Erickson, W., and Rubin, G, (1992). Effects of personal and occupational factors on sick building syndrome reports in air conditioned offices. In: Quick, J.C., Murphy, L.R., Hurrell Jr., J.J., ed., Work and well-being: assessments and interventions for occupational mental health, Chap. 19, Washington, D.C. American Psychological Association, pp. 286-98.

Hedge, A., Erickson, W.A. and Rubin, G. (1996). Predicting sick building syndrome at the individual and aggregate levels, Environment International, 22 (1), 3-19.

Heschong L, Wright RL, Okura S. (2002). Daylighting impacts on human performance in school. J Illum Eng Soc; 31(2):101-12.

Interpretations to ASHRAE Standard (15-1989), http://www.ashrae.org/technology/page/1835, last updated on August 19th, 2008.

Kaplan S. (1995). the restorative benefits of nature: toward an integrative framework. J Environ Psychol; 15:170-82.

Krieger J, Higgins DL. (2002). Housing and health: time again for public health action. Am J Public Health; 92:758-68.

Kuo FE, Sullivan WC. (2001). Environment and crime in the inner City: does vegetation reduce crime? Environ Behav; 33(3):341-64.

Milton DK, Glencross PM, Walters MD. (2000). Risk of sick leave associated with outdoor air supply rate, humidification, and occupant complaints. Indoor Air; 10(4):212-20.

National Heart, Lung, and Blood Institute Working Group. (1995). Respiratory diseases disproportionately affect minorities. Chest; 108:1380-92.

Saelens BE, Sallis JF, Frank LD. (2003). Environmental correlates of walking and cycling: findings from the transportation, urban design, and planning literatures. Ann Behav Med; 25:80-91.

Schroeder, H.W. (1991). Preferences and meaning of arboretum landscapes: combining quantitative and qualitative data. J. Environ. Psychol, 11, 231-242

Sick Building Syndrome. (1990). causes, effects and control, London Hazards Centre - Chapter 2, 4 Interchange Studios, Hampstead Town Hall Centre, London NW3 4QP, UK.

Ulrich R, Quan X, Zimring C, Joseph A, Choudhary R. (2004). The role of the physical environment in the hospital of the 21st century: a once-in-a- lifetime opportunity. Concord CA: Center for Health Design. www.healthdesign.org/research/reports/pdfs/role_physical_env.pdf.

Ulrich R. (1993). Biophilia, biophobia, and natural landscapes. In: Kellert S, Wilson EO, editors. The biophilia hypothesis. Washington, DC: Island Press. p. 138-72.

Wargocki P, Wyon D, Baik Y, Clausen G, Fanger P. (1999). Perceived air quality, sick building syndrome (SBS) symptoms and productivity in an office with two different pollution loads. Indoor Air; 9(3):165-79.

Wilson E. (1984). Biophilia. Cambridge, MA: Harvard University Press.

World Health Organization. (1983). Indoor air pollutants: exposure and health effects. EURO Reports and Studies 78, World Health Organization. 
Captions:

Table 1. Medical syndromes associated with buildings [Sick Building Syndrome, 1990, Chapter 2]

Table 2. Differences between indicators of SBS and BRI [Authors]

Table 3. Types of problem found in 203 indoor air quality investigations carried out by National Institute for Occupational Safety and Health (NIOSH) [Sick Building Syndrome, 1990, Chapter 4]

Table 4. Relationship between sustainable strategies and health co-benefits [Authors]

Table 1: Medical syndromes associated with buildings

\begin{tabular}{|ll|}
\hline \multicolumn{1}{|c|}{ Syndrome } & \multicolumn{1}{c|}{ Symptoms } \\
\hline Sick building syndrome(SBS) & Lethargy and tiredness \\
(1) Type 1 & Headache \\
& Dry blocked nose \\
& Sore dry eyes \\
& Sore throat \\
& Dry skin and/or skin rashes \\
\hline (2) Type 2 & Watering/itchy eyes and runny nose \\
& i.e. symptoms of an allergy such as hay fever \\
\hline Building related illness(BRI) & Generalized malaise \\
(1) Flu-like symptoms & Aches and pains \\
& Cough \\
& Lethargy \\
& Headache \\
\hline (2) Allergic reaction & Chest tightness \\
in sensitive individuals & Difficulty in breathing \\
& Fever \\
\hline (3) Occupational asthma & Headache \\
& Wheeze \\
& Chest tightness \\
& Difficulty in breathing \\
\hline
\end{tabular}

Source : Sick Building Syndrome: causes, effects and control - Chapter 2 C 1990 London Hazards Centre, Interchange Studios, Hampstead Town Hall Centre, 213 Haverstock Hill, London NW3 4QP, UK

Table 2 : Differences between indicators of SBS and BRI

\begin{tabular}{|c|c|}
\hline Indicators of SBS & Indicators of BRI \\
\hline $\begin{array}{c}\text { Building occupants complain of symptoms associated } \\
\text { with acute discomfort }\end{array}$ & $\begin{array}{l}\text { Building occupants complain of some long-lasting } \\
\text { symptoms }\end{array}$ \\
\hline $\begin{array}{c}\text { Most of the complaints report relief soon after } \\
\text { leaving the building }\end{array}$ & $\begin{array}{c}\text { Complaints may require prolonged recovery times } \\
\text { after leaving the building }\end{array}$ \\
\hline The cause of the symptoms is unknown & $\begin{array}{l}\text { The symptoms can be clinically defined and have } \\
\text { clearly identifiable causes }\end{array}$ \\
\hline
\end{tabular}

Source: [Authors] 
Table 3: Types of problem found in 203 indoor air quality investigations carried out by National Institute for Occupational Safety and Health (NIOSH)

\begin{tabular}{|c|c|c|c|}
\hline Problem & No. & $\%$ & Notes \\
\hline CONTAMINATION (INSIDE) & 36 & 18 & $\begin{array}{l}\text { Exposure to chemical or other toxic agent generated within } \\
\text { the office space, e.g. methyl alcohol from spirit duplicator, } \\
\text { methacrylate from a copier, sulphur dioxide from a heating } \\
\text { system, amines used in a humidification system, chlordane } \\
\text { used as a pesticide }\end{array}$ \\
\hline CONTAMINATION (OUTSIDE) & 21 & 10 & $\begin{array}{l}\text { Exposure to a chemical or other toxic substance originating } \\
\text { from a source outside the building, e.g. motor vehicle } \\
\text { exhaust fumes, construction activity, underground petrol } \\
\text { spillage }\end{array}$ \\
\hline $\begin{array}{l}\text { CONTAMINATION (BUILDING } \\
\text { FABRIC) }\end{array}$ & 7 & 3 & $\begin{array}{l}\text { Problems from the material used to construct the building } \\
\text { (figure excludes asbestos), e.g. formaldehyde, fiberglass }\end{array}$ \\
\hline INADEQUATE VENTILATION & 98 & 48 & $\begin{array}{l}\text { Symptoms may be due to low levels of multiple } \\
\text { contaminants and/or poor ventilation }\end{array}$ \\
\hline HYPERSENSITIVITY PNEUMONITIS & 6 & 3 & $\begin{array}{l}\text { Problems due to a reaction to micro-organisms in the } \\
\text { building environment }\end{array}$ \\
\hline CIGARETTE SMOKING & 4 & 2 & \\
\hline HUMIDITY & 0.9 & 4 & \\
\hline NOISE/ILLUMINATION & 2 & 1 & \\
\hline SCABIES & 1 & 0.5 & \\
\hline UNKNOWN & 19 & 9 & \\
\hline
\end{tabular}

Table 4: Relationship between sustainable strategies and health co-benefits

\begin{tabular}{|c|c|}
\hline SUSTAINABLE STRATEGIES & HEALTH CO-BENEFITS \\
\hline $\begin{array}{l}\text { INCREASE USE OF SUSTAINABLE, LOCAL OR } \\
\text { RECYCLED CONSTRUCTION MATERIALS }\end{array}$ & $\begin{array}{l}\text { REDUCED LEVELS OF RESPIRATORY ILLNESSES DUE TO } \\
\text { IMPROVED AIR QUALITY }\end{array}$ \\
\hline $\begin{array}{l}\text { USING MATERIALS WITH AUTHORITATIVE } \\
\text { GUARANTEES OF NON-TOXICITY }\end{array}$ & $\begin{array}{l}\text { RECUCED SBS AND BRI INSIDE THE BUILDINGS DUE } \\
\text { TO DECREASED TOXIC MATERIALS }\end{array}$ \\
\hline $\begin{array}{l}\text { INCREASE HEATING AND COOLING EFFICIENCY } \\
\text { THROUGH SITE ORIENTATION ,INSULATED } \\
\text { WINDOWS AND NATURAL VENTILATION } \\
\end{array}$ & $\begin{array}{l}\text { IMPROVED MENTAL HEALTH AND PRODUCTIVITY } \\
\text { FROM USE OF DAY LIGHTING }\end{array}$ \\
\hline $\begin{array}{l}\text { DESIGNING FOR HIGH FRESH AIR CHANGE RATE } \\
\text { ABOVE MINIMUM REQUIREMENTS }\end{array}$ & $\begin{array}{l}\text { REDUCED LEVELS OF MEDICAL SYNDROMES } \\
\text { ASSOCIATED WITH BUILDINGS }\end{array}$ \\
\hline $\begin{array}{l}\text { DESIGNING FOR EASY CLEANING AND } \\
\text { MAINTENANCE }\end{array}$ & $\begin{array}{l}\text { HEALTH PROBLEMS CAN ARISE THROUGH LACK OF } \\
\text { ANTICIPATED MAINTENANCE - CONSIDER THE } \\
\text { LIKELIHOOD AND EFFECTS OF BREAKDOWN IN } \\
\text { EXPECTED MAINTENANCE REGIMES }\end{array}$ \\
\hline $\begin{array}{l}\text { DESIGNING SO THAT THE BUILDING ITSELF OFFERS } \\
\text { INTERNAL CONDITIONS THAT ARE WITHIN OR } \\
\text { APPROACH CULTURALLY ACCEPTABLE LIMITS }\end{array}$ & $\begin{array}{l}\text { HEALTH PROTECTED THROUGH APPROPRIATE BUILT } \\
\text { ENVIRONMENT }\end{array}$ \\
\hline $\begin{array}{l}\text { DECREASE ELECTRICITY USE BY OCCUPANTS BY } \\
\text { PROVIDING CONVENIENT STAIRS, COMPACT } \\
\text { FLORESCENT BULBS, DAY-LIGHTING AND MOTION } \\
\text { SENSOR LIGHT SWITCHES }\end{array}$ & \\
\hline $\begin{array}{l}\text { USING ENERGY } \text {-USING SYSTEMS ONLY WHEN } \\
\text { APPROPRIATE IN RELATION TO OTHER } \\
\text { SUSTAINABILITY ISSUES }\end{array}$ & $\begin{array}{l}\text { INCREASED ENVIRONMENTAL HEALTH FOR } \\
\text { BUILDING OCCUPATIONS }\end{array}$ \\
\hline $\begin{array}{l}\text { EDUCATIONAL STRATEGIES IN ORDER TO FULLY } \\
\text { INFORMED THE CAUSES AND CONSEQUENCES OF } \\
\text { IAQ PROBLEMS TO OCCUPANTS SO THAT THEY CAN } \\
\text { WORK MORE EFFECTIVELY TOGETHER TO PREVENT } \\
\text { PROBLEMS FROM OCCURRING }\end{array}$ & $\begin{array}{l}\text { WHEN BUILDING OCCUPANTS, MANAGEMENT, AND } \\
\text { MAINTENANCE PERSONNEL FULLY COMMUNICATE AND } \\
\text { UNDERSTAND THE CAUSES OF IAQ PROBLEMS, THEY CAN SOLVE } \\
\text { HEALTH PROBLEMS MORE EASILY }\end{array}$ \\
\hline
\end{tabular}

